\title{
ACP1 wt Allele
}

National Cancer Institute

\section{Source}

National Cancer Institute. ACP1 wt Allele. NCI Thesaurus. Code C88196.

Human ACP1 wild-type allele is located in the vicinity of $2 \mathrm{p} 25$ and is approximately $23 \mathrm{~kb}$ in length. This allele, which encodes low molecular weight phosphotyrosine protein phosphatase protein, plays a role in the modulation of phosphorylation of both proteins and flavinoids. 